Personalidade Acadêmica Homenageada:

Augustus B. Cochran III (Agnes Scott College)

\title{
A MEDIDA PROVISÓRIA № 881/2019 E AS STARTUPS
}

\section{PROVISIONAL MEASURE No. 881/2019 AND STARTUPS}

\section{SANDRO MANSUR GIBRAN}

Advogado. Doutor em Direito Econômico e Socioambiental pela PUC-PR. Mestre em Direito Social e Econômico pela PUC-PR. Curitiba, Paraná, Brasil, sandro@rochaadvogados.com.

\section{JULIANA MARKENDORF NODA}

Advogada. Pós-graduanda em Sociologia Política pela UFPR. Curitiba, Paraná, Brasil, juliana_mnoda@hotmail.com.

\section{RESUMO}

A Medida Provisória no 881, editada em 30 de abril de 2019, ficou popularmente conhecida como a "Medida Provisória da Liberdade Econômica" e trouxe viés economicamente liberal no impacto de relevo a institutos jurídicos amplamente utilizados no Direito Empresarial. Ocorre que, sabe-se da debilitada participação da comunidade jurídica no debate sobre as alterações e seus possíveis efeitos, bem como questiona-se intensamente a legitimidade do instrumento utilizado para a edição da matéria, extremamente complexa, que poderia ter sido consolidada por meio do procedimento legislativo ordinário. Isto pois, o risco da sua perda de eficácia, seja pela rejeição expressa ou tácita, coloca em xeque a segurança jurídica das relações pactuadas no período de sua vigência. Sendo assim, trata-se dos novos aspectos introduzidos pela MP 881/2019, especialmente no que concerne ao tema das startups, que despertam ambiente de sucesso por meio da criação de novos produtos e serviços em setores relevante, assim como o 
Personalidade Acadêmica Homenageada:

Augustus B. Cochran III (Agnes Scott College)

da mobilidade urbana e o mercado financeiro, na busca por inovação. A MP 881/2019 buscou a criação de um ambiente favorável ao empreendedorismo, de modo a promover alterações legislativas com o objetivo de simplificar e desburocratizar a criação de novas empresas. Utilizou como base o inciso iv do caput e parágrafo único do art. 170, bem como o art. 174, ambos da Constituição Federal, estabelecendo normas de proteção à livre iniciativa e a liberdade econômica, além de consolidar novas diretrizes ao papel regulador do Estado. A metodologia empregada segue o padrão da revisão bibliográfica com a análise das últimas notícias relacionadas ao tema, dada sua atualidade, para o acompanhamento dos seus efeitos. Os resultados que se pretende atingir com o presente trabalho visam estudar os desdobramentos caso a Medida Provisória perca a sua eficácia e as possíveis implicações para o Direito Empresarial, considerando que o tema é bastante atual e as consequências jurídicas não estão absolutamente delineadas.

PALAVRA-CHAVE: Medida Provisória 881/2019; Liberdade Econômica; Direito Empresarial.

\section{REFERÊNCIAS}

BRASIL. Constituição da República Federativa do Brasil de 1988. Disponível em: <http://www.planalto.gov.br/ccivil_03/constituicao/constituicao.htm>. Acesso em 20 mai 2019.

BRASIL. Medida Provisória no 881, 30 de abril de 2019. Disponível em: <http://www.planalto.gov.br/ccivil_03/_ato2019-2022/2019/Mpv/mpv881.htm> Acesso em: 24 mai 2019

CAVALCANTI, Thais Novaes; TREVISAM, Elisaide. A Abordagem das Capacidades na Teoria de Amartya Sen sobre o Desenvolvimento Humano. Revista Jurídica Unicuritiba. V. 1. N. 54, 2019. Disponível em

<http://revista.unicuritiba.edu.br/index.php/RevJur/article/view/3305> Acesso em 02 mar 2019. 
Personalidade Acadêmica Homenageada:

Augustus B. Cochran III (Agnes Scott College)

CANOTILHO, J. J. GOMES. Direito constitucional. 6.ed. - Coimbra: Almeida, 1995.

COELHO, Fábio Ulhoa. Curso de direito comercial: direito de empresa, v. 2. 11. ed. São Paulo: Saraiva, 2008.

DINIZ, Maria Helena. Curso de direito civil brasileiro. 22. ed. v.1. São Paulo: Saraiva, 2005.

FANTONI JR, Neyton. Segurança Jurídica e Interpretação Constitucional. RJ 238/13. Ago/1997.

FIGUEIREDO, Elisa Junqueira; PERIGOLO, Thiago Schapiro. A MP da liberdade econômica e seus primeiros reflexos na desconsideração da personalidade jurídica. Disponível em <https://www.migalhas.com.br/dePeso/16,Ml302875,61044$\mathrm{A}+\mathrm{MP}+\mathrm{da}+$ liberdade+economica+e+seus+primeiros+reflexos+na>. Acesso em 26 mai 2019.

GAGLIANO, Pablo Stolze. A medida provisória da "liberdade econômica" e a desconsideração da personalidade jurídica (Art. 50, CC): primeiras impressões. Disponível em <http://www.flaviotartuce.adv.br>. Acesso em: 23 mai 2019.

GERMANOS, Paulo André Jorge (Coord.). Segurança jurídica. Rio de Janeiro: Elsevier, 2010.

LEONARDO, Rodrigo Xavier; RODRIGUES JUNIOR, Luiz Rodrigues. A MP da liberdade econômica: o que mudou no Código Civil? (parte 1). Disponível em $<$ https://www.conjur.com.br/2019-mai-06/direito-civil-atual-mp-liberdade-economicamudou-codigo-civil> Acesso em 25 mai 2019.

MAMEDE, Gladston. Manual de Direito Empresarial. 12 ed. São Paulo: Atlas, 2018.

MARINONI, Luiz Guilherme. Os precedentes na dimensão da segurança jurídica. Revista Jurídica. Sapucaia do Sul, v. 58, n. 398, p. 25-42, dez. 2010.

RAMOS, Elival da Silva. A proteção aos direitos adquiridos no direito constitucional brasileiro. São Paulo: Saraiva, 2003.

REALE, Miguel. Lições Preliminares de Direito. 24. ed. São Paulo: Saraiva, 1998.

SOUZA, Carlos Aurélio Mota de. Segurança Jurídica e Jurisprudência: um enfoque filosófico-jurídico. São Paulo: LTr, 1996.

TARTUCE, Flávio. A Medida Provisória n. 881/2019 (liberdade econômica) e as alterações do Código Civil. Primeira parte desconsideração da personalidade 
Personalidade Acadêmica Homenageada:

Augustus B. Cochran III (Agnes Scott College)

jurídica e função social do contrato. Disponível em >http://www.flaviotartuce.adv.br/>. Acesso em 25 mai 2019.

TOMASEVICIUS FILHO, Eduardo. MP da "liberdade econômica": o que fizeram com o Direito Civil?. Disponível em <https://www.conjur.com.br/2019-mai-13/direitocivil-atual-mp-liberdade-economica-fizeram-direito-civil>. Acesso em 24 mai 2019. 